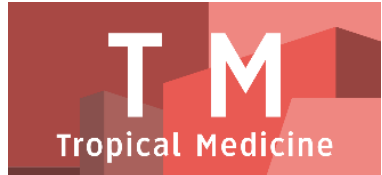

PAPER - OPEN ACCESS

\title{
Upaya Berhenti Merokok Terhadap Peningkatan Perawatan Diri Pasien dengan Penyakit Paru Obstruktif Kronik (PPOK)
}

\author{
Author : Mersi Ekaputri \\ DOI $\quad: 10.32734 /$ tm.v1i2.221 \\ Electronic ISSN $\quad: 2623-0550$ \\ Print ISSN : :2623-0542
}

Volume 1 Issue 2 - 2018 TALENTA Conference Series: Tropical Medicine (TM)

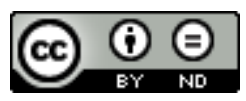

This work is licensed under a Creative Commons Attribution-NoDerivatives 4.0 International License.

Published under licence by TALENTA Publisher, Universitas Sumatera Utara
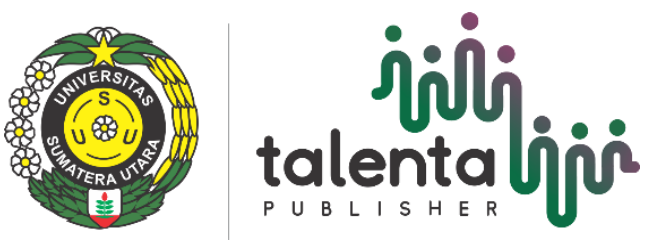


\title{
Upaya Berhenti Merokok Terhadap Peningkatan Perawatan Diri Pasien dengan Penyakit Paru Obstruktif Kronik (PPOK)
}

\author{
Mersi Ekaputri ${ }^{\mathrm{a}^{*}}$, Yesi Ariani ${ }^{\mathrm{a}}$ \\ Fakultas Keperawatan, Universitas Sumatera Utara 20155, Indonesia \\ mersiputri12@yahoo.com
}

\begin{abstract}
Abstrak
Kebiasaan merokok adalah salah satunya penyebab kausal yang terpenting untuk penyakit PPOK. Asap rokok mempunyai prevalensi yang tinggi sebagai penyebab gejala respirasi dan gangguan fungsi paru.Prevalensi PPOK selalu mengalami peningkatan dengan makin banyaknya perokok karena $90 \%$ penderita PPOK adalah perokok atau mantan perokok. Upaya untuk membantu individu untuk mencapai tingkat kesehatan yang optimal adalah dengan memberikan edukasi menghindari pencetus (berhenti merokok). Tujuan dari penelitian ini adalah untuk mengidentifikasi upaya edukasi untuk berhenti merokok dengan peningkatan perawatan diri pasien dengan penyakit paru obstruktif kronik (PPOK). Desain penelitian quasi eksperimen pre and post tet dengan48 responden yang diambil secara consecutive sampling.Uji statistik yang digunakan yaitu Wilcoxon Signed Rank Test terdapat perbedaan upaya berhenti merokok antara sebelum intervensi dengan sesudah intervensi edukasi, rerata self care sebelum intervensi dengan mean 6.78 dan setelah intervensi 10.38 serta $p$ value 0.00 dengan artian terdapat perubahan upaya edukasi berhenti merokok antara sebelum dan sesudah intervensi pada pasien PPOK. Diharapkan peran dan upaya aktif tenaga kesehatan untuk membantu pasien PPOK berhenti merokok.
\end{abstract}

Keyword : Perawatan diri Pasien; Penyakit Paru;Obstruktif Kronik;

\section{Pendahuluan}

Penyakit paru obstruksi kronis (PPOK) adalah: penyakit paru yang dapat dicegah dan diobati yang ditandai dengan adanya keterbatasan aliran udara persisten dan umumnya bersifat progresif, berhubungan dengan respon inflamasi kronik yang berlebihan pada saluran napas dan parenkim paru akibat gas atau partikel berbahaya. Eksaserbasi dan komorbid berkontribusi pada beratnya penyakit. Karakteristik hambatan aliran udara pada PPOK disebabkan oleh gabungan antara obstruksi saluran napas kecil (obstruksi bronkiolitis) dan kerusakan parenkim (emfisema) yang bervariasi pada setiap individu, akibat inflamasi kronik yang menyebabkan hilangmya hubungan alveoli dan saluran napas kecil dan penurunan elastisitas rekoil paru [1].

World Health Organization (WHO) dalam Global Status of Non-communicable Diseases, 2010 mengkategorikan PPOK ke dalam empat besar penyakit tidak menular dengan angka kematian serta beban kesehatan tertinggi setelah penyakit kardiovaskular, keganasan dan diabetes[2].

Prevalensi PPOK di Asia Pasifik tahun 2012 adalah 6,2\% dan sekitar 19,1\% merupakan pasien PPOK derajat berat dengan angka prevalens 5,6\% di Indonesia dan 9,5\% di Taiwan[3]. Data di Indonesia untuk prevalensi PPOK $3,7 \%$ akan meningkat dengan bertambahnya usia dan lebih tinggi pada laki-laki $(4,2 \%)$ dibandingkan perempuan $(3,3 \%)[4]$. 
Penderita PPOK selain mengalami penurunan faal paru juga mengalami gangguan ekstrapulmonal serta sering mengalami gejala-gejala yang mengganggu seperti sesak napas, kehilangan nafsu makan, keterbatasan aktivitas yang menghambat penderita untuk melakukan aktivitas sehari-hari sehingga menyebabkan ketergantungan pada orang sekitar dan tentunya sangat mempengaruhi kualitas hidup[5].

Salah satu strategi penatalaksanaan PPOK adalah edukasi dengan harapan untuk meningkatkan pengetahuan tentang perawatan diri dimana pengetahuan perawatan diri sebagai landasan untuk manajemen diri penyakit kronis. Pemahaman pasien terhadap kondisi kesehatan serta bagaimana menjalani hidup pasca didiagnosa penyakit dapat membawa pasien pada pemberdayaan dan kualitas hidup yang baik [6].

Edukasi merupakan proses interaktif yang mendorong terjadinya pembelajaran dan pembelajaran merupakan upaya menambah pengetahuan baru, sikap, serta keterampilan melalui penguatan praktik dan pengalaman tertentu [7]. Salah satu lingkup edukasi adalah edukasi atau pendidikan kesehatan.

Edukasi kesehatan adalah proses yang direncanakan dengan sadar untuk menciptakan peluang bagi individuindividu untuk senantiasa belajar memperbaiki kesadaran (literacy) serta meningkatkan pengetahuan dan keterampilannya (life skills) demi kepentingan kesehatannya [8].

Tujuan edukasi adalah untuk membantu individu, keluarga, atau komunitas dalam mencapai tingkat kesehatan optimal dengan inti edukasi adalah menyesuaikan keterbatasan aktifitas dan mencegah perburukan fungsi paru dengan salah satu edukasi upaya untuk menghindari pencetus (berhenti merokok). Hasil dari penelitian menyimpulkan bahwa dampak dari tidak diberikannya edukasi berpengaruh terhadap tidak terkendalinya penyakit, potensial terjadinya komplikasi, menurunnya kualitas hidup pasien serta tingginya angka rehospitalisasi [9]

\section{Lokasi dan Metode Penelitian}

\subsection{Lokasi Penelitian}

Penelitian dilakukan di RS. Khusus Paru Sumatera Barat Kota Padang pada pasien PPOK yang barobat jalan.

\subsection{Metode}

Desain penelitian quasi eksperimen dengan menggunakan desain pre-tes and post-test group design yaitu memberikan perlakuan atau intervensi pada subjek penelitian kemudian mengukur dan menganalisis efek dari perlakuan [9]. Jenis sampling yang iaodigunakan yaitu consecutive sampling atau pemilihan sampel dengan menetapkan subjek yang memenuhi kriteria inklusi penelitian dimasukkan dalam penelitian sehingga jumlah sampel yang ditentukan dapat terpenuhi [9]. Perhitungan jumlah sampel memakai tabel Power Analysis dengan power $(1-\beta)=.80$, effect size $(\gamma)=.60$ dan $\alpha=.05$. Didapatkan jumlah sampel dalam penelitian ini adalah 44 orang. Dalam upaya mengantisipasi kemungkinan subjek atau sampel yang terpilih drop out maka perlu penambahan jumlah sampel $10 \%$ agar besar sampel tetap terpenuhi sehingga total sampel didapatkan 48 responden.

Kriteria inklusi dalam penelitian ini adalah: pasien dengan diagnosa PPOK, derajat PPOK berat dan sangat berat berdasarkan Mmrc, tidak mengalami gangguan kognitif, mampu berkomunikasi verbal yang baik, mampu membaca dan menulis serta bersedia menjadi responden serta hadir dalam sesi edukasi.

Kriteria ekslusi pasien yang mengalami penurunan kesadaran selama penelitian berlangsung, sedang mengalami serangan eksaserbasi berat pada saat penelitian serta adanya faktor komorbid: Ca paru dan gangguan jantung.

Sebelum mengambil data, peneliti telah mendapatkan surat ijin penelitian dari direktur RS khusus Paru Sumatera Barat dan surat lolos kaji etik dari Komisi Etik Penelitian Kesehatan Universitas Sumatera Utara. Pengumpulan data dilakukan setelah mendapatkan persetujuan dari responden untuk ikut serta dalam penelitian ini. Media untuk edukasi pasien diberi modul tentang upaya berhenti merokok. Alat pengumpul data dalam penelitian ini kuesioner dan data karakteristik responden. Pretest dilakukan dengan meminta pasien untuk mengisi kuesioner sebelum dilakukan intervensi selanjutnya dilakukan intervensi pemberian edukasi dan lembar aktifitas harian responden terkait perawatan diri responden dalam keseharian responden. intervensi dilakukan selama 2 minggu, frekuensi 3 kali dalam seminggu dengan waktu 30 menit tiap sesi edukasi dan setelah itu dievaluasi kembali diminggu ke 4 dimana pasien dimintak kembali untuk mengisi kuesioner. 
Analisis data dilakukan dengan menggunakan software SPSS versi 16. Uji normalitas data dilakukakan dengan uji skewness dan kurtosis. Hasil uji menunjukkan bahwa data tidak berdistribusi secara normal. sehingga data dalam penelitian ini menggunakan uji non parametrik Wilcoxon Signed Rank Test untuk menguji perbedaan rata-rata sebelum dan sesudah dilakukan intervensi. Pada penelitian ini setelah dilakukan uji Wilcoxon Signed Rank Test didapat nilai $\mathrm{p}<0.00$, yaitu kurang dari nilai $\alpha(0.05)$ sehingga dapat disimpulkan adanya perbedaan nilai self care sebelum dan sesudah dilakukan intervensi edukasi yang memberdayakan pasien.

\section{Hasil dan Pembahasan}

\subsection{Hasil}

Deskripsi subjek penelitian didapatkan bahwa usia pasien mayoritas pada rentang usia 56 - 65 tahun (lansia akhir) 25 orang (52.1\%). Jenis kelamin responden mayoritas adalah laki-laki yaitu 45 orang (93.8\%). Untuk riwayat status merokok sudah berhenti 26 orang (54.2\%), lama merokok mayoritas $\geqslant 20$ tahun 44 orang (91.6\%).

Tabel 1 Distribusi Frekuensi dan Persentase Data Karakteristik Pasien PPOK di Poliklinik Paru Rs Paru Sumatera Barat $(\mathrm{N}=48)$.

\begin{tabular}{|c|c|c|c|}
\hline No & Karakteristik & $\mathbf{F}$ & $\%$ \\
\hline \multirow[t]{6}{*}{1} & Umur & & \\
\hline & $36-45$ tahun (Dewasa Akhir) & 3 & 6.2 \\
\hline & $46-55$ tahun (Lansia Awal) & 8 & 16.7 \\
\hline & $56-65$ tahun (Lansia Akhir) & 25 & 52.1 \\
\hline & $>65$ tahun (Manula) & 12 & 25.0 \\
\hline & $\begin{array}{l}\text { Mean 60.52, SD } 7.96 \\
\text { Min-Max 40-75 }\end{array}$ & & \\
\hline \multirow[t]{3}{*}{2} & Jenis Kelamin & & \\
\hline & Laki-laki & 45 & 93.8 \\
\hline & Perempuan & 3 & 6.2 \\
\hline \multirow[t]{5}{*}{3} & Riwayat Status Merokok & & \\
\hline & Tidak pernah & 1 & 2.1 \\
\hline & Sudah berhenti & 26 & 54.2 \\
\hline & Masih merokok & 20 & 41.7 \\
\hline & Perokok pasif & 1 & 2.1 \\
\hline \multirow[t]{4}{*}{4} & Lama Merokok & & \\
\hline & Tidak ada & 2 & 4.2 \\
\hline & $\geq 20$ tahun & 44 & 91.6 \\
\hline & $<20$ tahun & 2 & 4.2 \\
\hline
\end{tabular}

Tabel 3. Data rerata upaya berhenti merokok sebelum dan sesudah Intervensi diPoliklinik Paru Rs Paru Sumatera Barat $(\mathrm{N}=48)$

\begin{tabular}{|l|l|l|l|l|}
\hline No & \multicolumn{1}{|c|}{ Kelompok subjek intervensi } & \multicolumn{1}{c|}{ Pre-test } & Pos-test & pvalue \\
\hline 1 & Mean & 6.78 & 10.38 & 0.000 \\
\hline 2 & SD & 1.842 & 1.864 & .269 \\
\hline 3 & SE & .266 & & \\
\hline
\end{tabular}

Berdasarkan tabel 3 menunjukkan bahwa terdapat perbedaan peningkatan self care antara sebelum dan sesudah intervensi. Data diatas menunjukkan bahwa peningkatan self care setelah diberikan intervensi, rerata self care 
sebelum intervensi dengan mean 6.78 dan setelah intervensi 10.38. uji Wilcoxon Signed Rank Test didapat nilai $\mathrm{p}<$ 0.00 , yaitu kurang dari nilai $\alpha(0.05)$ sehingga dapat disimpulkan adanya perbedaan rata-rata nilai upaya berhenti merokok sebelum dan sesudah dilakukan intervensi edukasi.

\subsection{Pembahasan}

Edukasi merupakan hal penting dalam pengelolaan jangka panjang pada PPOK stabil. Edukasi pada PPOK berbeda dengan edukasi pada asma. Karena PPOK adalah penyakit kronik yang ireversibel dan progresif, inti dari edukasi adalah menyesuaikan keterbatasan aktifitas dan mencegah kecepatan perburukan fungsi paru yang salah satu upaya yang dapat dilakukan yaitu dengan berhenti merokok [5].

Penatalaksanaan PPOK dapat dilakukan dengan dua macam terapi yaiu pemberian terapi secara farmakologis dan terapi non-farmakologis seperti berhenti merokok. Edukasi dan arahan oleh tenaga kesehatan merupakan sesuatu yang penting untuk menghentikan kebiasaan merokok. Upaya dalam menghentikan kebiasaan merokok memberikan efek yang positif untuk mengurangi gejala dari pada penyakit PPOK[5].

Pada penelitian ini didapatkan adanya hubungan antara berhenti merokok dengan perawatan diri pasien PPOK. Hasil penelitian ini sama dengan penelitian yang dilakukan kepada 113 pasien dengan PPOK yang masih merokok dan mengikuti program berhenti merokok dalam waktu 12 minggu didapatkan hasil penelitian tersebut menunjukkan skor CAT pasien PPOK yang berhenti merokok lebih rendah dibandingkan pasien PPOK yang tidak mengikuti program berhenti merokok[10].Kualitas hidup pasien PPOK yang berhenti merokok lebih baik daripada pasien PPOK yang masih merokok. Berhenti merokok pada pasien PPOK menyebabkan penurunan risiko terjadinya eksaserbasi bila dibandingkan dengan pasien yang masih merokok dan hal ini juga dipengaruhikepada pada lamanya seseorang (responden) penelitian berhenti merokok dengan artian bahwa semakin lama seseorang sudah berhenti merokok maka semakin menurun risiko untuk mengalami kejadian serangan eksaserbasi karena faktor merokok menjadi peyebab respons inflamasi yang berperan pada patogenesis PPOK. Inflamasi ini berperan sangat penting untuk meningkatkan risiko eksaserbasi.[11]. Dari hasil wawancara didapatkan pasien yang mengalami peningkatan pada post-test self care mengatakan bahwa dengan edukasi mereka dapat mengelola penyakit PPOK yang dialaminya sehingga mampu untuk memanajemen diri menghindari faktor pencetus (berhenti merokok).

\section{Daftar Pustaka}

[1] Global Initiative for Chronic Obstructive Lung Disease (GOLD). (2015). Global strategy for the diagnosis, management, and prevention of chronic obstructive pulmonary disease. National Institutes of Health. National Heart, Lung and Blood Institute.

[2] Soeroto, A.Y., \& Suryadinata, H. (2014). Penyakit Paru Obstruksi Kronis. Journal Ina J Chest Crit and Emerg Med. Vol. 1, No. 2 hal 83-88

[3]Lim, S., Lam, D.C., Muttalif, A.R., Yunus, F., Wongtim, S., Lan le, T.T., Shetty, V., et al. (2015). Impact of chronic obstructive pulmonary disease (COPD) in the Asia-Pacific region: the EPIC Asia population-based survey. Asia Pacific Fam Med: 14:1-1. doi: 10.1186/s12930015-0020-9

[4] Riset kesehatan dasar, 2013

[5] Penyakit Paru Obstruksi Kronik diagnosis dan penatalaksanaan. Perhimpunan Dokter Paru

Indonesia (PDPI). (2016) Jakarta: Universitas Indonesia (UI-Press)

[6]Nursalam \& Efendi, F. (2008). Pendidikan dalam keperawatan. Jakarta: Salemba Medika.

[7]Smeltzer, S.C., \& Bare. G. (2008). Brunner and Suddarth's tex book of medical surgical nursing (11 th ed). Philadelpia: Lippincott.

[8]Abedi, H., Salimi, S., Feizi, A., \& Safari, S. (2013). Effect of self-efficacy enhancement program on self-care behaviors in chronic obstructive pulmonary disease.Iranian Journal of Nursing and Midwifery Research. Vol. 18 |: 421-424. Diunduh pada tanggal 12 September 2016 dari https://www.ncbi.nlm.nih.gov/pmc/articles/PMC3877467/

[9]Polit, D.F., \& Beck, C.T. (2012). Nursing research: generating and assending evidence for nursing practice. Philadelphia: Wolters Kluwer, Lippincott Williams \& Wilkins

[10]Postolache P, Nemes RM, Petrescu O, Merisanu IO. Smoking cessation, pulmonary rehabilitation and quality of life at smokers with COPD. Rev Med Chir Soc Med Iasi. 2014; 119(1):77-80.

[11]Au DH, Bryson CL, Chien JW, Sun H, Udris EM, Evans LE, et al. The effects of smoking cessation on the risk of chronic obstructive pulmonary disease exacerbations. J Gen Intern Med. 2009; 24:457-63. 